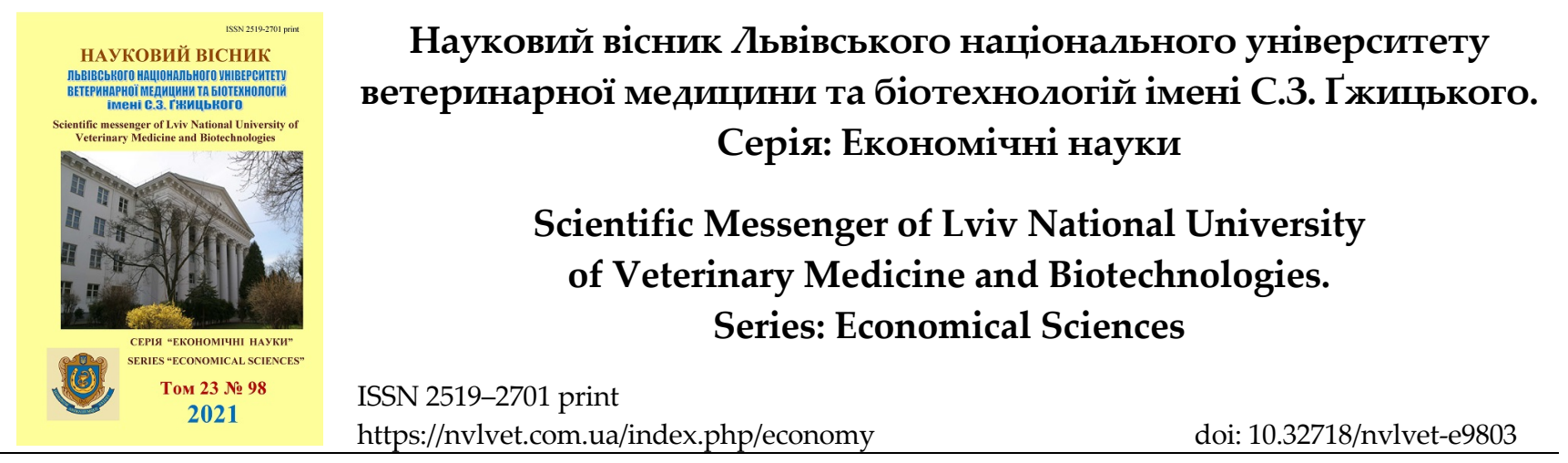

UDC: 658.628

\title{
Formation of the product portfolio of the enterprise
}

\author{
N. Voytovych, A. Bulavinets
}

Stepan Gzhytskyi National University of Veterinary Medicine and Biotechnologies Lviv, Lviv, Ukraine

Article info

Received 15.10.2020

Received in revised form 29.11.2020

Accepted 01.12.2020

Stepan Gzhytskyi National University of Veterinary Medicine and Biotechnologies Lviv,

Pekarska Str., 50, Lviv, 79010,

Ukraine. Tel.: +38-032-39-26-39

E-mail:marketing@lvet.edu.ua
Voytovych, N., \& Bulavinets, A. (2021). Formation of the product portfolio of the enterprise. Scientific Messenger of Lviv National University of Veterinary Medicine and Biotechnologies. Series: Economical Sciences, 23(98), 17-22. doi: 10.32718/nvlvet-e9803

Management decisions on the formation of the product portfolio are traditionally in the field of research of scientists as the relevance questions of the choice of strategic goals of the enterprise involves the justification of marketing and production decisions in optimizing the structure of the product range. The formation of the product portfolio involves certain management actions to work with a particular product (its development, withdrawal or modification) or range of products, taking into account changes in the structure of the portfolio of the enterprise. Today's market situation creates new requirements for existing approaches to product development; at the same time such efforts must directly take into account the aggregate market and business requirements for reduced lead time, reliable product performance and costeffective product differentiation. In general, one way to meet the increased demand for product development speed and productivity is to identify multidisciplinary synergies that can be used to increase system efficiency. The main principles that were singled out allow to develop a practical system for decision support which will allow effectively form the product portfolio of the enterprise and develop optimal characteristics of the product and its product range group. The methodology of decision support is based on interdisciplinary integration, which is formed by using the main relationships between optimization and modelling of a product or group of products as well as aspects of product portfolio management. Scientific and methodological approaches in the formation of the company's portfolio were substantiated which allows to determine the optimal ratio between the range of products and product units that are part of them. The LLC "Khodoriv Meat Packing Factory" is one of the leading producers of meat products in Ukraine. Product range was analysed and the method of quantitative evaluation of goods indicators is proposed to factory. The system approach to formation of an optimum commodity portfolio of the enterprise is considered. The analysed of the assortment group of goods and the assessment of the product portfolio of the enterprise by the method of the Boston Consulting Group (BCG). Positioning of strategic business units was carried out. The desired assortment group of goods was selected, which will help the company to achieve its goals. The basic marketing strategies are offered.

Keywords: product portfolio of the enterprise, marketing strategy, product range.

\section{Формування товарного портфеля підприсмства}

\author{
Н. Войтович, А. Булавінець
}

Львівський національний університет ветеринарної медицини та біотехнологій імені С. 3. Гжсицкого, м. Львів, Україна

Управлінські рішення щуодо формування товарного портфеля традиційно знаходяться у полі дослідження науковців, оскільки актуальність питань вибору стратегічних ичілей підприємства передбачає обтрунтування маркетингових $і$ виробничих рішень при оптимізацї структури асортименту продукції. Формування товарного портфеля передбачає певні управлінські дї шедо роботи з окремим товаром (його розробку, виведення або модифікацію) чи асортиментом товарів враховуючи зміни структури портфеля підприємства. Сьогоднішня ситуація на ринку створює нові вимоги до існуючих підходів щуодо розробки продукиії; при иььому такі зусилля повинні безпосередньо враховувати сукупні ринкові та бізнес-вимоги до скороченого терміну виконання, надійної продук- 
тивності продукиії та рентабельної диференціації продукиії. Узагальнено, щчо одним із способів задоволення підвищеного попиту на швидкість розробки продукту та підвищення продуктивності є виявлення мультидисциплінарних синергій, які можна використати для підвищення ефективності системи. Виокремлено основні засади, щуо дозволять розробити практичну систему щзоо підтримки прийняття рішень, яка дозволить ефективно формувати товарний портфель підприємства та розробляти оптимальні характеристики продукту і його асортиментної групи. Методологія підтримки прийняття рімень спирається на міждисциплінарну інтеграчію, яка формується шляхом використання основних залежностей між оптимізачією та моделюванням товару чи групою товарів, а також аспектами управління товарного портфелю підприємства. Обтрунтовано науково-методичні підходи у формуванні портфеля підприємства, щчо дозволяє визначити оптимальні співвідношення між асортиментними групами продукції та товарними одинииями, які входять до їхнього складу. Проаналізовано товарний асортимент продукиії ТзОВ “Ходорівський м'ясокомбінат” та запропоновано методику кількісної оцінки показників товарів. Розглянуто системний підхід до формування оптимального товарного портфеля підприємства. Здійснено аналіз асортиментної групи товарів та оцінку товарного портфеля підприємства методом Бостонської консалтингової групи (БКГ). Проведено позиціювання стратегічних одиниць бізнесу. Виокремлено бажану асортиментну групу товарів, яка сприятиме підприємству досягнення поставлених цілей. Запропоновано основні маркетингові стратегіi.

Ключові слова: товарний портфель підприємства, маркетингова стратегія, товарний асортимент.

\section{Вступ}

Останнім часом ринок та суспільство висували нові та більш жорсткіші вимоги до галузей аграрного сектору, що призвело до таких заходів, як поточна реструктуризація та раціоналізація. Протягом багатьох років, компанії все-таки визнали обмеження цих заходів для досягнення стійкої прибутковості. Світовий попит на харчові продукти оцінюється приблизно у 10 трлн дол. США - до цієї суми входять як харчові продукти, так і послуги харчування, які охоплюють кейтеринг для компаній та приватних споживачів. Продаж харчових продуктів охоплює понад 80 \% європейського ринку, а на послуги харчування припадають лише 20 \% загального обсягу (Sektoralna eksportna stratehiia..., 2019). Компанії все частіше обирають розширення товарної лінійки, включаючи спеціальні продукти 3 високою доданою вартістю через потенціал зростання.

Однак відсутність стандартних рамок для підтримки ефективної розробки продуктів в складних ринкових умовах, а також відсутність теоретичних прогнозних моделей для кількісної оцінки їх ефективності на ринку часто створюють проблеми для виробників. Крім того, акцент на дизайні товару обов'язково фокусується на початкових рішеннях, що стосуються форми товару, і зменшує акцент на виробництві (Moggridge \& Cussler, 2000).

Таким чином, в результаті зміни фокусу від специфікації композиції до продуктивності кінцевого використання продукту, вимагає більшої участі замовника у розробці продукту, щоб забезпечити шанси на успіх продукту. Крім того, в результаті зростання агропродукції, ринок створює допоміжні виклики завдяки розширенню асортименту продукції та похідних складностей управління.

Актуальність теми. У сучасній світовій економіці виробники харчової продукції стикаються із дедалі складнішими проблемами, що виникають внаслідок тиску на ціноутворення, інтенсивної конкуренції, зростання матеріальних витрат та коливань на ринку (Sektoralna eksportna stratehiia..., 2019). На цьому тлі компанії постійно намагаються визначити ініціативи та стратегії, які дозволять їм підтримувати зростання та покращувати норму прибутку. Крім цього економічного тиску, компанії стикаються $з$ додатковими вимогами через швидкі технологічні зміни із застосуванням нанота мікротехнологій (Charpentier, 2009). Ці економічні та технологічні зміни супроводжуються великим ринковим попитом на швидкість та диференціацію продуктів (Hill, 2009).

Останнім часом було запропоновано багато підходів щодо формування товарного портфеля підприємства, зокрема зарубіжними авторами: (McAllister \& Simpson, 2003; Georgiopoulos et al., 2005; Michalek et al., 2006; Besharati et al., 2006). Формування товарного портфеля передбачає певні управлінські дії щодо роботи $з$ окремим товаром, які означають процес обгрунтування включення чи розробку нового товару до товарного портфеля, виведення товару, а також модифікації наявних товарів і зміни структури портфеля (Cravens \& Nigel, 2009).

У цьому дослідженні ми вважаємо, що одним із способів задоволення підвищеного попиту на швидкість розробки продукту та підвищення продуктивності $\epsilon$ виявлення мультидисциплінарних синергій, які можна використати для підвищення ефективності системи.

Зокрема, Besharati et al. (2006) представив інтегрований підхід до дизайну та маркетингу, щоб полегшити створення оптимального надійного набору альтернативних варіантів дизайну продуктів для переходу до наступного етапу процесу розробки продукту. Також він пропонує якісну структуру, яка послідовно пов'язує прийняття бізнес-рішень, тобто стратегічних рішень із розробкою продуктів і процесів.

Однак, згідно Georgiopoulos et al. (2005) кращий підхід до зв'язування виробничих та технологічних вимог із бізнес-рішеннями передбачає кількісну оцінку взаємозалежності між ними. Для кількісної оцінки зв'язку між технологіями та бізнес-плануванням застосували просту фінансову модель та інженерну імітаційну модель для отримання рішення щодо розподілу ресурсів при розробці продукції.

Таким чином, ми зосереджуємося на інтеграції товарного асортименту та формуванні товарного портфеля як ефективної стратегії забезпечення оптимальних виробничих та економічних показників.

Проблема формування та моделювання оптимального товарного портфеля починається з базового визначення вимог до створення нового продукту та має на меті визначити та розробити такий асортимент, який би відповідав потребам споживачів.

3 іншого боку, у дослідженні (Riehl et al., 2019) було висловлено думку, що труднощі, що виникають при прийнятті портфельних рішень, пов’язані з про- 
блемами, що існують на рівні розробки товарного асортименту. Ці фактори підкреслюють важливість управління портфелем для зусиль, спрямованих на розробку продукції, а отже, і для загальної діяльності фірми (McAllister \& Simpson, 2003).

Інші дослідження також припускають, що такі реакції бізнесу, як надмірне акцентування уваги на швидкості виходу на ринок, короткочасна зайнятість та перевантаження проектів, призвели до проблем управління портфелем та збою продукту (Michalek et al., 2006).

Мета і завдання дослідження. Метою є обгрунтування науково-методичних підходів у формуванні портфеля підприємства, що дозволяє визначити оптимальні співвідношення між асортиментними групами продукції та товарними одиницями, які входять до їхнього складу.

\section{Матеріал і методи досліджень}

Дослідницькі матеріали в цій статті містять вторинні джерела інформації: зарубіжні та вітчизняні публікації; дані з веб-сайтів: ТзОВ "Ходорівський м'ясокомбінат", Головне управління статистики у Львівській області, Міністерство економічного розвитку і торгівлі України. Період дослідження - $2017-$ 2019 pp.

У роботі використано якісний метод - спостереження в галузі нових інноваційних технологій на підприємствах харчової промисловості. Основні положення, висновків і пропозиції наукової роботи опубліковані: у науковому журналі "Альманах науки", Київ, 2019 р. (Voitovych \& Bulavinets, 2019) та викори- стані ТзОВ "Ходорівський м'ясокомбінат" (довідка впровадження № 9 від 09.02.2021р.).

\section{Результати та їх обговорення}

В останні десятиліття, формування, оптимізація та управління товарним портфелем набувають все більшого значення, оскільки фірми прагнуть реагувати на зростаючий попит, що посилюються, глобальною конкуренцією та швидко мінливими технологіями (Cravens \& Nigel, 2009).

Товарний асортимент та дизайн продукту є завершальним етапом у процесі розробки продукту, який включає ряд заходів, що призводять до продуктивності продукту та технічних характеристик виробничого процесу. Загалом процес проектування продукту включає ряд лінійних етапів як показано на рис. 1 .

Процес проектування товару також може характеризуватися набором рішень, які приймаються з метою задоволення як технічних, маркетингових, так і економічних вимог до даного товару. Серед найважливіших рішень, які слід прийняти в процесі проектування, $є$ рішення, що стосуються вибору та встановлення пріоритетів проектних завдань та вибору маркетингових стратегій. В процесі прийняття рішень щодо розробки товарного асортименту продукту вагомий внесок $є$ як від осіб, які приймають рішення про портфель бізнесу, так і від команди розробників продуктів. I навпаки, в науково-дослідних та дослідноконструкторських організаціях остаточне рішення щодо інвестицій у новий товар приймається в контексті нового товарного асортименту.

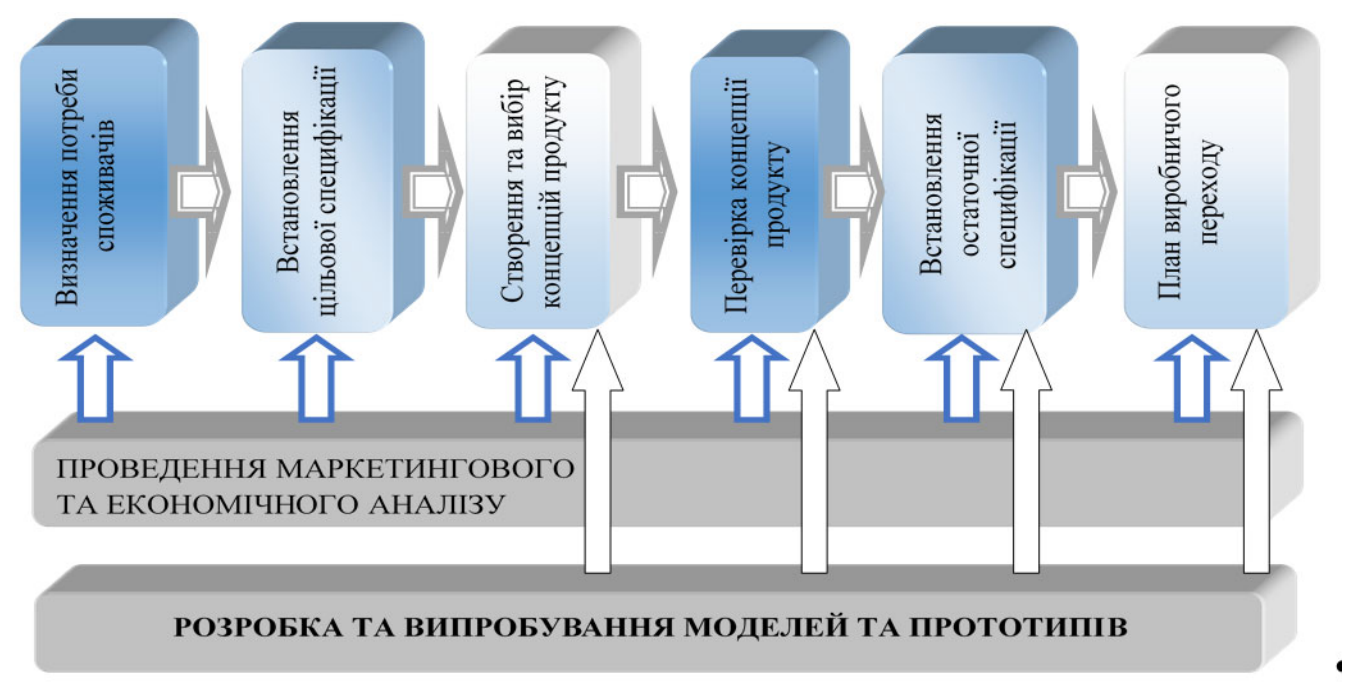

Рис. 1. Процес загального проектування продукту

Джерело: складено автором на основі: (Michalek et al., 2006; Charpentier, 2009; Hill, 2009; Voitovych \& Bulavinets, 2019)

Говорячи про формування товарного портфеля підприємства виокремимо його основні засади, які подано на рис. 2.

Аналізуючи думки авторів та рис. 2, можемо підкреслити, що розробка практичної системи щодо підтримки прийняття рішень, дозволить ефективно планувати дизайн продукту та розробляти оптимальні характеристики продукту, його асортиментної групи.
Запропонована методологія підтримки прийняття рішень спираються на міждисциплінарну інтеграцію, яка формується шляхом використання основних залежностей між оптимізацією та моделюванням товару чи групою товарів, а також аспектами управління товарного портфелю підприємства. 


\section{ПРОЦЕС ФОРМУВАННЯ ТОВАРНОГО ПОРТФЕЛЯ МАЕ ВРАХОВУВАТИ:}

технічні, технологічні можливості доступну ресурсну базу (сировинне, виробництва фінансове, трудове забезпечення)

\section{ФОРМУВАННЯ ТОВАРНОГО ПОРТФЕЛЯ МАЄ БАЗУВАТИСЯ НА:}

оцінюванні рівня задоволення клієнтів і споживачів створеної ціннісної пропозиції підприємства передбачати можливість адаптації товарних пропозиції внаслідок динамічності ринкових умов

УПРАВЛІННЯ ТОВАРНОГО ПОРТФЕЛЯ МАЕ БУТИ:

\begin{tabular}{|c|c|c|}
\hline $\begin{array}{c}\text { безперервним, гармонізованим } \\
\text { конкурентною стратегією } \\
\text { підприємства }\end{array}$ & $\begin{array}{c}\text { враховувати вплив зовнішніх } \\
\text { (ринкових) і внутрішніх } \\
\text { (ресурсних) можливостей } \\
\text { пілприємства }\end{array}$ & $\begin{array}{c}\text { враховувати різні стратегічні і } \\
\text { функціональні аспекти } \\
\text { оцінювання товарного } \\
\text { портфеля }\end{array}$ \\
\hline
\end{tabular}

\section{ТОВАРНИЙ ПОРТФЕ.ІЬ МАЕ БУДУВАТИСЯ НА ПРИНЦИПАХ:}

збалансованості, з урахуванням стадій життєвого циклу продуктових груп і окремих асортиментних позицій
3 урахуванням особливостей управлінського впливу на зовнішні і внутрішні чинники функціонування і розвитку підприємства в короткостроковому і довгостроковому періодах

\section{ПРИЙНЯТТЯ РІШЕННЯ МАС ЗДІЙСНЮВАТИСЯ НА ОСНОВІ:}

якісної інформації - достовірної, повної, адекватної, об'єктивної та актуальної особи, що приймають ці рішення, мають використовувати не тільки фактичні, а й прогнозні дані

Рис. 2. Засади щодо формування товарного портфеля підприємства

Джерело: складено автором на основі (Moggridge \& Cussler, 2000; McAllister \& Simpson, 2003; Georgiopoulos et al., 2005; Michalek et al., 2006; Besharati et al., 2006; Charpentier, 2009; Voitovych \& Bulavinets, 2019)

Об'єктом дослідження товарного асортименту нами обрано підприємство - ТзОВ "Ходорівський м'ясокомбінат" (Veb-sait TzOV "Khodorivskyi miasokombinat").

Доцільно провести аналіз асортиментної групи товарів ТзОВ “Ходорівський м'ясокомбінат" методом Бостонської консалтингової групи $B C G$ (БКГ). В табл.
1 подано частку ринку, яку займає підприємство по видах товарів і основного конкурента - ПП “Старицький м'ясокомбінат”. Далі будуємо матрицю $B C G$ (БКГ) та визначаємо по ній можливі стратегії для ТзОВ “Ходорівський м'ясокомбінат” на основі інформації матриці, яка подана на рис. 3. 
Таблиця 1

Характеристика асортиментного портфеля

\begin{tabular}{|c|c|c|c|c|c|c|}
\hline \multirow{2}{*}{$\begin{array}{l}\text { Асортиментна } \\
\text { позиція }\end{array}$} & \multicolumn{2}{|c|}{$\begin{array}{c}\text { Обсяг продаж } \\
\text { тис. грн } \\
\end{array}$} & \multirow{2}{*}{$\begin{array}{l}\text { Ріст } \\
\text { ринку }\end{array}$} & \multicolumn{2}{|c|}{ Доля ринку, \% } & \multirow{2}{*}{$\begin{array}{c}\text { Відносна } \\
\text { частка ринку }\end{array}$} \\
\hline & 2017 p. & 2019 p. & & $\begin{array}{c}\text { ТзОВ “Ходорівський } \\
\text { м'ясокомбінат" }\end{array}$ & $\begin{array}{l}\text { ПП “Старицький } \\
\text { м’ясокомбінат” }\end{array}$ & \\
\hline Варено-копчені ковбаси & 29630 & 45390,7 & 0,65 & 33 & 30 & 1,1 \\
\hline Напівкопчені ковбаси & 42670 & 41270 & 1,03 & 36 & 28 & 1,29 \\
\hline Сосиски, сардельки & 18960 & 24760,2 & 0,77 & 16 & 20 & 0,8 \\
\hline Делікатесна група & 14220 & 15130,2 & 0,94 & 12 & 17 & 0,71 \\
\hline Інша м’ясна продукція & 13040 & 11000,5 & 1,18 & 11 & 5 & 2,2 \\
\hline Всього & 118520,8 & 137560,8 & 0,86 & 100 & 100 & 1 \\
\hline
\end{tabular}

Джерело: власні розрахунки

За даними матриці (див. рис. 3), можна зробити висновок про те, що продукція, яка знаходяться в квадраті “Дикі кішки” може стати “Зірками”, якщо застосуємо маркетингову стратегію розвитку товару. А “Зірки” у подальшому, з переходом до стадії зрілості перетворяться на “Дійних корів”. Товари, що знаходяться в квадраті "Зірки" необхідно оберігати і зміцнювати, тобто необхідно підтримувати, вкладаючи інвестиції. Товарів в категорії “Собак” ТзОВ “Хо- дорівський м'ясокомбінат" не має, що позитивно характеризує асортиментний портфель підприємства. Таким чином, ТзОВ “Ходорівський м'ясокомбінат" має оптимальну комбінацію продуктів “Дикі кішки”, “Зірки” i “Дійні корови”, що призведе до найкращих результатів функціонування - помірній рентабельності, хорошої ліквідності і довгостроковому зростанню збуту і прибутку.

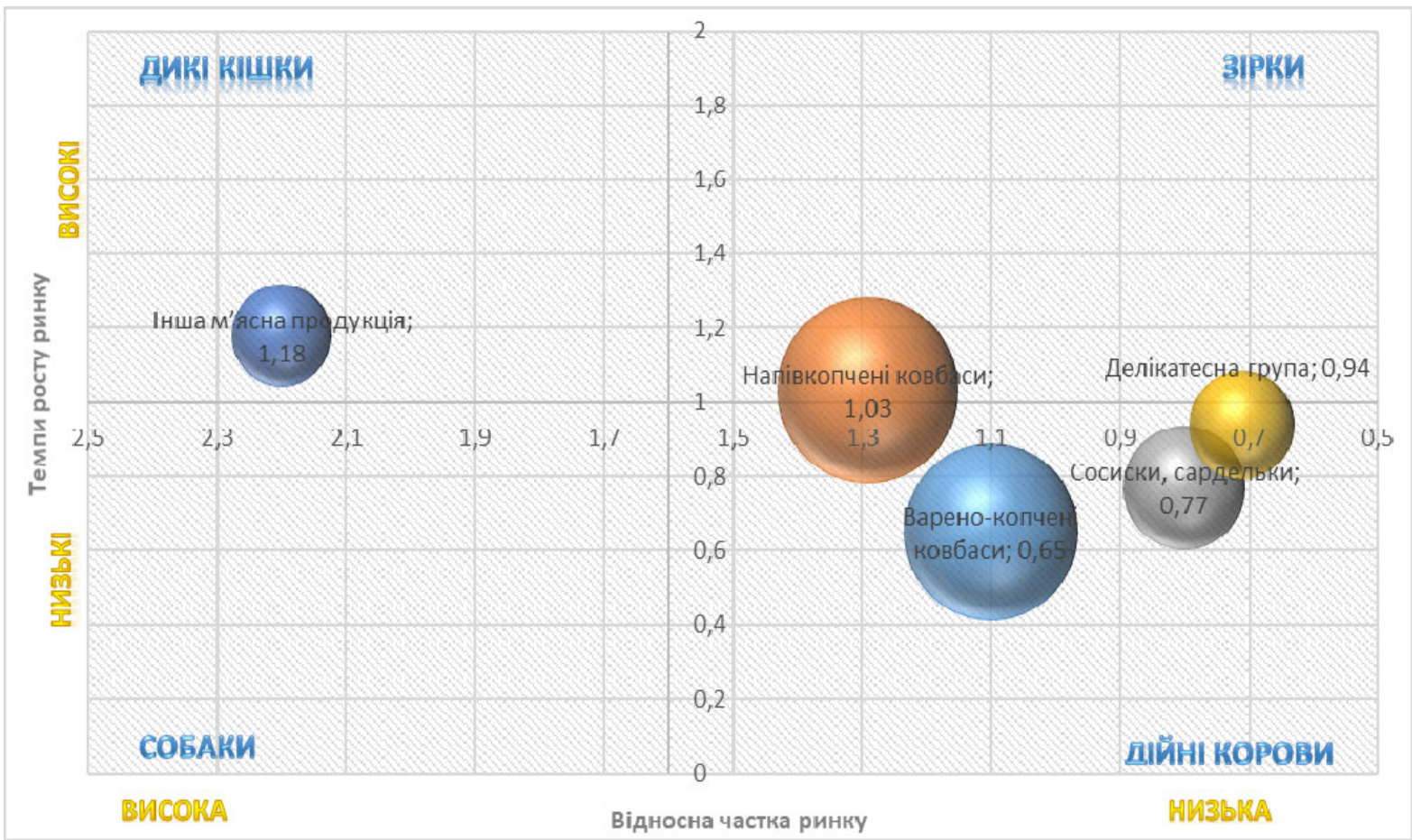

Рис. 3. Матриця Бостонської консультативної групи асортиментної групи ТзОВ “Ходорівський м’ясокомбінат” Джерело: власні дослідження

Отже, що стосується товарного асортименту ТзОВ "Ходорівський м'ясокомбінат”, то варто було б спрямувати інвестиції на розробку нового товару. А далі спробувати вийти на новий ринок з новим товаром застосувавши маркетингову стратегію диверсифікації.

Створення й освоєння нових видів продукції повинно стати основним питанням у плані технічного розвитку та організації діяльності підприємства. Нові товари дозволять підприємству змінити структуру асортименту і підтримати обсяг продажу на рівні, що забезпечить стабільне фінансове становище та конкурентоспроможність підприємства.

\section{Висновки}

Проведено аналіз запропонованої методології, яка стосується застосування мультидисциплінарної інтеграції та використання неявного взаємозв'язку між оптимізацією товарного асортименту та управлінням товарним портфелем. У цьому дослідженні ми використовуємо підхід матриці, щоб проілюструвати взаємозв'язок між асортиментом товару та управлінням товарним портфелем та сприяти їх інтеграції. Отже, на основі проведеного портфельного аналізу ТзОВ “Ходорівський м'ясокомбінат” можемо стверджувати, 
що дане підприємство має великий потенціал розвитку в майбутньому. За умови правильного використання своїх матеріальних, технічних, технологічних, фінансових, інформаційних та інших можливостей воно зможе міцно укріпити позиції на вітчизняному ринку. Правильний вибір стратегії забезпечить їі повну реалізацію, що буде мати позитивний ефект для подальшого розвитку та утримання провідних позицій бізнесу на ринку.

Перспективи подальших досліджень. Переформатування товарного портфеля дасть можливість сформувати оптимальну структуру товарних груп. Застосування таких інтегративних підходів до розробки продуктів пропонує інноваційну відповідь на зростаючі вимоги ринку до швидкості та вартості, одночасно задовольняючи бізнес-потреби в ефективному розподілі ресурсів. До особливостей цих нових систем підтримки входить невід'ємна гнучкість, яка дозволяє дискреційний вибір продуктової діяльності разом із обмеженою масштабованістю запропонованих підходів.

\section{References}

Besharati, B., Luo, L., Azarm, S., \& Kannan P. K. (2006). Multi-objective single product robust optimization: an integrated design and marketing approach. Journal of Mechanical Design, 128(4), 884-892. doi: $10.1115 / 1.2202889$.

Charpentier, J.-C. (2009). Perspective on multiscale methodology for product design and engineering. Computers and Chemical Engineering, 33(5), 936946. doi: 10.1016/j.compchemeng.2008.11.007.

Cravens, D., \& Nigel, F. (2009). Strategic marketing. [9th ed.]. USA: McGraw-Hill Companies.

Georgiopoulos, P., Jonson, M., \& Papalambros, P. Y. (2005). Linking optimal design decisions to the theory of the firm: the case of resource allocation. Journal of Mechanical Deign, 127(3), 358-366. doi: 10.1115/1.1862679.
Hill, M. (2009). Product and process design for structured products. AIChE Journal, 50(8), 1656-1661.

McAllister, C. D., \& Simpson, T. W. (2003). Multidisciplinary Robust Design Optimization of an Internal Combusition Engine. Journal of Mechanical Deign, 123, 123-130.

Michalek, J. J., Ceryan, O., Papalambros, P. Y., \& Koren, Y. (2006). Balancing marketing and manufacturing objectives in product line design. Journal of Mechanical Design, 128(6), 1196-1204. doi: $10.1115 / 1.2336252$.

Moggridge, G. D., \& Cussler, E. L. (2000). An introduction to chemical product design. Chemical Engineering Research and Design, 78(1), 5-11. doi:10.1205/026387600527022.

Riehl, C., Koch, T., \& Beckert, J. (2019). The importance of communicating change. Identifying predictors for support and resistance towards organizational change processes. Corporate Communications An International Journal, 24(4), 28. doi: 10.1108/CCIJ04-2019-0039.

Sektoralna eksportna stratehiia 2019-2023 rr. Kharchova i pererobna promyslovist Ukrainy. Ministerstvo ekonomichnoho rozvytku i torhivli Ukrainy. URL: https:/www.me.gov.ua/ (data zvernennia 10.10.2021) (in Ukrainian).

Veb-sait TzOV "Khodorivskyi miasokombinat": URL: https://khodorivmk.com/ (data zvernennia 08.10.2021) (in Ukrainian).

Voitovych, N. V., \& Bulavinets, A. Ia. (2019). Modeliuvannia tovarnoho portfelia yak chynnyk pidvyshchennia ekonomichnoi efektyvnosti pidpryiemstva. Almanakh nauky, 2/1(23), 8-13. URL: http://almanah.ltd.ua/save/2019/2\%20(23)/102.pdf (data zvernennia 10.10.2021) (in Ukrainian). 